\author{
${ }^{1}$ K.T. Tairova, ${ }^{2}$ G.O. Tazhina \\ ${ }^{1}$ graduate student, e-mail: tkamila6131@gmail.com \\ ${ }^{2} \mathrm{PhD}$, Director of the Center for Social Research, \\ e-mail: tazhina.g@uib.kz,https://orcid.org/0000-0001-7500-5648 \\ University of International Business, Kazakhstan, Almaty
}

\title{
CAREER ANCHORS AND ORGANIZATIONAL COMMITMENT IN GENERATIONS' PERSPECTIVE: AN OVERVIEW OF THE LITERATURE
}

\begin{abstract}
Issues of career preferences are tangible theoretical and practical concerns of any society. From the viewpoint of the Generations Theory, the representatives of X, millennials and the baby boomer generations are currently the productive societal job-force. The trajectory and development of their professional career is determined by the degree of reciprocity between the personality psychological potential and the content and requirements of professional activity, including the extent of employee's organizational commitment. In this paper, we provide an overview of the research pertaining to career preferences/anchors and organizational commitment in major workforce generations' perspective. The literature review was conducted using a variety of databases and sources were broadly centered around the following issues: career anchors and those of different generations; generations' perceptions of organizational commitment; how career anchors and organizational commitment are interrelated. The reviewed articles were grouped within each issue using the authors' findings to analyze gaps in the research.
\end{abstract}

Key words: career anchors, organizational commitment, generation X, Millennials, baby boomers.

\author{
${ }^{1}$ К.Т. Таирова, ${ }^{2}$ Г.О. Тажина \\ ${ }^{1}$ магистрант, e-mail: tkamila6131@gmail.com \\ ${ }^{2} \mathrm{PhD}$, Әлеуметтік зерттеулер орталығының Аиректоры, \\ e-mail: tazhina.g@uib.kz, https://orcid.org/0000-0001-7500-5648, \\ Халықаралық, бизнес университеті, Қазақстан, Алматы қ.
}

\section{Мансаптық бағдарлар және ұйымдастырушылық бейімдікік: ұрпақтар көзқарасы}

Аңдатпа. Мансапты таңдау сұрақтары кез келген қоғамдағы өзекті теориялық және практикалық мәселе болып табылады. Ұрпақтар теориясы тұрғысынан қазіргі уақытта үш буын өкілдері қоғамның өндіргіш күші болып табылады, атап айтқанда, Х ұрпағы, милменниалдар немесе Ү ұрпағы және бейби бумер ұрпағы сияқты. Тағы да, олардың кәсіби мансабының траекториясы мен дамуы жеке тұлғаның психологиялық мүмкіндіктерінің кәсіби қызметтің мазмұнымен және талаптарына сәйкес келу деңгейімен анықталады, оның ішінде қызметкердің ұйымшылдық, дәрежесімен. Сонымен қатар, осы мақалада біз мансаптық таңдауларға немесе мансапты бағдарларға байланысты зерттеулерге шолу жасаймыз және жұмыс күшінің негізгі ұрпақтарына тән қызметкердің ұйымдық міндеттілігі. Және де, әр түрлі мәліметтер базасын қолдана отырып, әдебиеттерге шолу жүргізілді және дереккөздер негізінен келесі мәселелерге шоғырланды: әртүрлі ұрпақ қызметкерлеріне арналған мансаптық таңдаулар деп аталатын немесе мансаптық шешімдер; үш түрлі ұрпақты қабылдаудағы ұйымдастырушылық міндеттемелер; қызметкерлердің мансаптық таңдаулары мен ұйымдық міндеттемелерінің байланысы. Әрі қарай, қарастырылған әдеби дереккөздер зерттеліп, әр мәселе бойынша топтастырылды, авторлардың тұжырымдарын қолдана отырып, осы мәселелер бойынша зерттеулердегі ақпараттың жетіспеушілі талдауға арналған.

Түйін сөздер: мансаптық бағдарлар, ұйымдастырушылық бейілділік, Х ұрпағы, мимлениалдар, Бейби Бумер ұрпағы. 


\author{
${ }^{1}$ К.Т. Таирова, ${ }^{2}$ Г.О. Тажина \\ ${ }^{1}$ магистрант, e-mail: tkamila6131@gmail.com \\ 2PhD, Аиректор Центра социальных исследований, \\ e-mail: tazhina.g@uib.kz, https://orcid.org/0000-0001-7500-5648, \\ Университет международного бизнеса, Казахстан, г. А^маты
}

\title{
Карьерные ориентации и организационная приверженность: точки зрения поколений
}

\begin{abstract}
Аннотация. Вопросы карьерных предпочтений являются актуальной теоретической и практической проблемой в ^юбом обществе. С точки зрения теории поколений, в настоящее время производительной силой социума являются преАставители трех поколений, таких как поколение X, милменниалы и поколение бейби бумер. Траектория и развитие их профессиональной карьеры определяются степенью согласованности психологических возможностей кичности с содержанием и требованиями профессиональной деятельности, в том числе степенью организационной приверженности работника. В этой статье мы представляем обзор исследований, которые касаются карьерных предпочтений, или якорей карьеры, и организационной приверженности сотрудника, характерных Аля основных поколений трудовых ресурсов. Обзор литературы проводился с использованием различных баз данных, и источники были в основном сосредоточены вокруг следующих вопросов: карьерные предпочтения, или якоря карьеры сотрудников разных поколений; организационная приверженность в восприятии трех разных поколений; взаимосвязь карьерных предпочтений и организационной приверженности работников. Рассмотренные митературные источники были изучены и сгруппированы по каждому поставленному вопросу с использованием выводов авторов Аля того, чтобы проанализировать пробелы в исследованиях по Аанным вопросам.
\end{abstract}

Кмючевые слова: карьерные ориентации, организационная приверженность, поколение X, мимленниалы, поколение бейби бумер.

\section{Introduction}

Nowadays, major part of economic and welfare are influenced by rational use of human resources. Qualified specialists play a crucial role in country development. Due to the current changes people have alternative vision of their career. The old terms are terms, such as, stability, predictability, security of job are replaced with life-long learning, multiple careers and flexibility (Cascio, 2001). Furthermore, young specialists pay more attention to their individual needs in order to enhance their career and future. According to Schein the significant role is played by self-insight as employees are responsible for their future career (Schein, 1990). Therefore, the universities are considered to be an important part for human growth (Ashwin, 2006). In accordance to Lick, universities are suggested to re-assemble its rules and conditions to adapt to modern world needs and be efficient for new specialists. As teachers have a great impact on new potencial emplyees, the university government should pay attention more to the teachers (Ghalavandi, 2010).

Motivation of activity and self-actualization is reflected in career orientation, which is considered as a disposition of the highest level, is a stable education and determines the professional path of a person. In career orientation values, motives of activity, personal, semantic formations are integrated, therefore it can be considered as orientation of the person on realization of itself in activity (Zharkikh et al, 2014)

One of the most essential point of professional development is conscious selection of career path. Career involves successful advancement in the field of public, political, professional activities. Planning of the career is carried out by the person, proceeding from the General tendencies of self-actualization, self-knowledge, an actual condition of the motivational sphere. A professional career is a part of a person's life in which private, personal and public interests merge.

Sociologists have been studying the notion of "generation" for a long time. Generation unites members of the same age and values. Millennials, people who were born between 1981 and 1996, in comparison to previous generation $\mathrm{X}$, people born between 1965 and 1981, have different work values and career perception. They are supposed to be more smart and competent as they were born on the boarder of technological revolution (Aydogmus, 2018). In addition, the generation $\mathrm{Y}$ is supposed to be more restless and do not always obey organizational rules, while The Baby Boom Generation (born between 1946 and 1964), believed in having one working place for the rest of their lives and in loyalty to their company; (Silva, et al., 2016).

The problem of generations, and in particular their characteristic features, in the situation of rapid socio-economic transformations in recent de- 
cades has become the subject of attention of sociological, cultural and pedagogical studies of Western and domestic scientists. Thus, the popular "theory of generations", developed by American scientists demographer N. Howe and historian W. Strauss in the 1990s. The researchers found that about every 20 years there is a new generation with their own values, representatives of which behave differently from their predecessors at the same age. The authors interpreted the generation as a certain category of people born in a certain era and influenced by the same phenomena and principles of development (Shindryaeva, 2015)

Howe and Strauss believe that the social generation is a set of people born in the same period of twenty years and have three General criteria: age position in history, which implies the experience of the same historical events at about the same age, common, common beliefs and behaviors and a sense of belonging to this generation (Ozhiganova, 2015).

Currently, more and more attention is paid to the loyalty of the employees to their organization. Major part of practitioners considers the problem of loyalty as extremely urgent for the employee-employer relationship, to improve labor efficiency, and for the quality of the entire domestic business.

Both in English language and in Russian language literature, there are many different points of view on employees of workers' organizations. Defining the subject field, it is necessary, first of all, to designate one of the most common views on staff loyalty - a view from the point of view of. In accordance to this approach, employees should identify and eliminate the consequences for illegal behavior (Dominyak, 2006).

One of the leading researchers of organizational commitment, Natalie Allen and John Meyer, note that in Western organizational psychology among studies on work preferences, studies of commitment are widespread. This is determined, firstly, by the interest in the possibility of preventing the staff turnover, and secondly, by the conviction that a loyal employee is more profitable than disloyal or indifferent one (Allen and Meyer, 2000).

Increasing employee loyalty to their organizations allows them to increase their efficiency, which is one of the most important socio-economic problems in our country at the moment. Therefore, tools are needed to predict loyalty, as well as choose managerial influences to increase it. This requires studies of trends in the development of loyalty and the mechanisms underlying it. On the other hand, given the fragmented views on loyalty, it is necessary to analyze and systematize the data of existing studies, on the basis of which it would be possible to propose a model for the development of loyalty taking into account current trends in the relations between the employee and the organization (Dominyak, 2006).

In this paper, we provide an overview of the research pertaining to career anchors and organizational commitment in generations' perspective. The literature review was conducted using a variety of databases Education Resources Information Center (ERIC), Google Scholar, JSTOR: Journal Storage, PsycINFO, Pub Psych. The sources were broadly centered around the following issues: 1. Career anchors and those of different generations; 2. Generations' perceptions of organizational commitment; 3 . How career anchors and organizational commitment are reciprocal and interrelated. Finally, the articles were grouped within each issue using the authors' findings to analyze and to look for gaps in the research.

\section{Career anchors and those of different genera- tions}

The term career anchors, introduced by Schein in 1978, can be applied for any employee rank. It is supposed that employees are more loyal to a company, if their personal needs are fulfilled as well as organization needs. The notion of career anchors is significantly important in constantly changing world of work (Schein, 1996). In addition, he claims that career anchors were developed in order to help employees to adopt to their organization and make effective decisions during their career path (Schein, 1990).

It is supposed by Tsaritsentsaeva that career orientations begin to form in the process of University training, at the early stages of professionalization. In the 3rd-4th year career orientations of students are manifested in the features of setting career goals and further career planning (Tsaritsentsaeva, 2010).

One of the studies was focused on Generation Y's career perception. For conducting the research, 189 participants from catholic University in Brazil were invited. All of them represented Business Administration major. As tools two surveys were taken: the Schein's career anchors questionnaire and Schwartz's survey on values of respondents. After the survey, the author used statistical technique to analyze the data. Besides statistical relationships, the author notes that lifestyle anchor is more characterized among smaller group of participants while, the general management career anchor is more frequent among larger group (Silva, et al., 2016)

According to Ozhiganova the generation $\mathrm{Y}$ is a completely new generation that requires a special 
approach and a special system of training and motivation. Employers should take into account the main features of this generation and apply new developments to it, such as: training in the format of games, flexible schedules, the possibility of rapid career growth, constant monitoring and issuing accurate instructions, constant creative tasks and opportunities to Express themselves. However, it should not be forgotten that such recommendations are applicable only to lower and middle-ranking positions, as well as positions with a low level of responsibility. More serious positions continue to occupy representatives of generation X. therefore, the study of the generation of "Millennials" and the characteristics of their behavior remains extremely relevant and popular direction for the modern world (Ozhiganova, 2015).

Aydogmus, in his thesis, identifies how the Millennials' career anchors and career attitudes are interconnected. For the research 492 engineers, who were born after 1981, were selected for the survey. According to the results, Millennials' psychological authorization is tied to their career attitude. That had a great impact on hierarchical regression as well. Consequently, the author insists, that employers should pay attention to Millennials' empowerment which is influential for their career attitudes and anchors (Aydogmus, 2018).

The notion "career anchors" formed during a long time. According to Schein, a person does not have the career anchors, unless he or she gets enough experience to be able to identify the career anchor. However, if the individual could define his or her career anchors, the career choices would be easier and more efficient for that person (Schein, 1990).

According to Polyanskaya, career anchors or career orientations are defined as representations of their abilities, value orientations, motives, meanings and needs related to the advancement in professional activity, are considered as the most important component of the I-concept. Career orientations arise in the process of socialization, are actualized in the situation of choice, the subject is guided by them when choosing and modeling his professional and life path in General. In the structure of the professional I-concept of the individual there is not one, but a certain hierarchy of career orientations, which may vary slightly under the influence of life circumstances with a low degree of variability of certain dominant orientations

The career anchors refers to the job peculiarities that encourage employees to work. Originally in the 1970s, Schein defined five anchors that have impact on career decisions. After conducting some research, he added three more aspects by the 1980s.
Schein believed that those who changed their job were adopted to complete the operations they used to do in previous workplace.

The first anchor developed by Schein is techni$\mathrm{cal} /$ functional competence, which refers to the employees who get a autonomy and copes with a certain challenges while working. The second anchor, is general managerial competence associated with a person who is eager to lead and manage within organization. Moreover, those individuals are aimed to get high hierarchical position. The following component is called autonomy/independence which refers to people who seek for freedom in his or her workplace, while the next security and stability anchor is related to individuals, who seek for stable and secure work position. Also, there is entrepreneurial creativity, which means that a person is oriented on his or her business. The sixth anchors, which is called service/dedication to one cause, is distinctive for people who look for tasks connected with personal values. It is supposed that those people would change a job easily if it does not meet his or her life values. The seventh component is pure challenge. The employees are characterized by having a strong desire to problem solve. Those individuals need to feel that they win really hard competition while solving complicated tasks. The final anchor, lifestyle, refers to people who seek for balance between career and private life. Usually, they build their career depending on their place or spouses.

In order to determine individual career anchors, Schein made up a special stock of questions which may facilitate the characterization of an employee. The questionnaire consists of forty statements that a surveyee have to rank from 1 to 6 . The survey includes such notions as, skills and abilities, motivation and demands, values and attitude.

Schein believes that career anchors are natural for any culture. Moreover they differ among different cultures. Consequently, the system of career development should be adopted to certain features of a culture. For instance, it will not be efficient for a large multi-national company to apply the same system or lead the same dialogue in their subsidiaries all over the world (Schein, 1990).

The modern generation of leaders (baby boomers and generation $\mathrm{X}$ ) for successful development it is necessary to undergo certain changes, as they are employed by people with a completely different Outlook, the same representatives of generation Y.

Russian studies of career orientations using the theory ofE. Shane began in the 2000s with the work of L. G. Pochebut, V. A. Chiker. The authors presented the results of the study of career orientations in 
Russia. The career preferences of the Russian youth were as follows: the orientation on integration of lifestyles, autonomy and service dominated among schoolchildren; College students - on integration of lifestyles, autonomy, stability; students - on service, integration of lifestyles, autonomy. Similar data on the sample of students was described in the works of A. V. Kaluderovic. Young people appreciate the balance of work and other aspects of life, freedom, the opportunity to use their skills and talents to serve an important purpose, for many people the needs for safety and security that underlie the choice of career anchor "stability"are significant. Leading career preferences of students are social in nature, in General, are not associated with professional orientation to a particular specialty, in our opinion, may reflect age characteristics (Polyanskaya, 2014).

\section{Generations' perceptions of organizational commitment}

There is no common opinion in the scientific literature regarding the definition of the concept of "Organizational commitment", therefore, researchers have different approaches to this problem, which in turn makes it impossible to form a unitary descriptive approach.

Organizational commitment has been studied beginning from the $1980 \mathrm{~s}$, however there was not a clear definition of the notion. Thus, according to O'Reilly \& Chatman organizational commitment is characterized by whether an employee is tied to an organization and whether he or she feels involved and loyalty towards the workplace (O'Reilly, Chatman, 1986). On the other hand, Cohen claims that the concept of organizational commitment means "the relative strength of an individual's identification with and involvement in an organization" (Cohen, 1993).

Allen and Mayer claim that there are plenty of methods to determine organizational commitment. According to their study, where they examined three-component model of commitment, the first component is called affective (Allen, Mayer, 1990). It is related to emotional bond of employee and organization where he or she works. Moreover, it shows how staff members are involved in their workplace. The next component that was considered by Allen and Mayer is continuance competent. The term means that an employee who were mastering his or her skills for a certain position would think about whether that would be paid off before changing his or her job. The third normative component is closely connected with individuals' obligations. That means, if a person has strong feeling of responsibility and loyalty towards an organization, he or she would stay longer in the company. In their first study they developed certain scales to estimate the given components. While the second study shows the relationship between the findings in study one with different variables. As a result, the authors concluded that affective and continuance components are distinguished and correlated. Moreover, affective component has strong relationship with normative one (Allen and Meyer, 1990).

Ivanova claims that approach, according to which loyalty implies the emotional affection of the employee to the organization, which is formed through a set of combinations: previous work experience, personal characteristics of the employee and perception of the organization. These characteristics lead to a positive attitude towards the organization, which in turn leads to loyalty (Ivanova, 2019).

At the same time, Jans proposed his definition of loyalty, which implies a certain degree to which the individual perceives the values and goals of the organization, considering his own organizational role in terms of his contribution to them (Jans, 1989).

Zangaro supposes that there is one more type of organizational commitment, called alienative commitment. Furthermore, the author insists that this type appears when a person feels he or she has no impact on own workplace, so he or she wants to quit the job. In addition, this kind of employee does not perform in a good way while working (Zangaro, 2001).

Allen and Meyer developed a special survey in order to identify how loyal an employee is. The questionnaire contains eight questions for each component. As well as in questionnaire of career anchors, participants are supposed to rank the given statements from 1 to 5 .

Jaros in his critical analysis of Meyer and Allen's three-component model of organizational commitment discusses the scales for measuring all thee given components. He also suggests that in order to get to accurate scales in the Meyer and Allen's model, certain challenges must be solved and improved (Jaros, 2007).

Michael and O'Malley in his book Creating Commitment: How to Attract and Retain Talented Employees by Building Relationships that Last builds his five-element loyalty model.

Conformity and affiliation (the need to be accepted) - how much the employee feels his significance, and his interests, values coincide with the values, interests of the organization. 
Status and individuality (need for respect), this indicates the extent to which the employee is proud of his company.

Trust and reciprocity (need for security) - how strongly the employee feels that the company takes into account his interests.

Emotional reward (need for development) - to what extent the employee experiences the pleasure of working in the organization, satisfaction with what activities he is engaged in.

Economic interdependence (need for funds) how much the employee agrees with the received salary

According to Dominyak, organizational commitment is shaped on the basis of the individual's subjective perception of various situations, including organizational, previous behavior of and their interpretation, taking into account the current individual motivational picture. Profiles of the career and motivational attractiveness of the organization, as well as profiles of career orientations and motivational expectations of the employee allow us to analyze the compatibility and prospects of cooperation between the person and the organization (Dominyak, 2006).

It is supposed that if managers are aware of reasons of employees different behavior, it would be easier for them to motivate their employees. Gray $\&$ Starke identify three steps of this process. The first one is understanding. It refers to defining key predictors of a certain situation, at prediction stage, there will be an opportunity to predict the behavior on the basis of previous observations. Finally, when managers understand and may guess the behavior, they would be able to control the staff members (Gray \& Starke, 1988).

Rocha claims that it is not only the company that benefits from organizational commitment, but people working there can see the advantages as well. For instance, they are less stressed by instability either in terms of finance and emotional state (Rocha et al, 2008).

In 2003 Musto researched the differences between X generation and Baby Boomer generation. His main focus was organizational commitment among two age groups. He found out that for older generation it was quite important to have prestige, hierarchical status and respect, while generation $\mathrm{X}$ still valued prestige and respect. However, for those, who were born after 1981, status is gained not hierarchically, but through enhancing qualification and mastering skills. The same situation was for payment matter. Baby boomers were accustomed to stable payment corresponding to hierarchical position, whereas Millennials preferred payment coinciding the employee's performance (Musto, 2003).

Benson and Brown believe that employees born before 1964 are accustomed to their workplace and loyal to the organization they work in. Moreover, group work and discussions are crucial for them. They believe in long - term job and often sacrifice a lot in order to succeed. Whereas, generation $\mathrm{X}$ is described as independence seekers. Furthermore, they are supposed not to have a long-term loyalty towards their company (Benson, Brown, 2009).

James Musto, conducted a comparative study of the Baby boomers and generation $\mathrm{X}$ members in 2003. In the study the cohort differences which affect organizational commitment in the two groups were examined. This study was conducted on the theoretical basis of organizational commitment from the multiple component perspective as discussed by Allen and Meyer. Organizational commitment in the aforementioned theory is defines as having three independent components namely, affective commitment, normative commitment and continuance commitment. Where affective commitment; is an individual emotional attachment to the organization, normative commitment is described as feeling of duty and obligation to the organization while continuance commitment, is caused by difficulties associated with changing jobs (Musto, 2003).

Another study conducted in 2006 among IT specialists included 382 professionals from different universities. The participants were representatives of two generations: Baby boomers and generation $\mathrm{X}$. The goal of the research was the examination of work attachment and organizational commitment. The authors characterize the organizational commitment as homogenous rather than diverse (Davis et al., 2006).

Ling and Yuen suppose that loyal employees is a competitive feature of any organization.Regardless that, nowadays staff members have lower organizational commitment in comparison to the previous generation. According to their study, the research aim is determining personal characteristics and organizational commitment are closely inerdependent. The knowledge of this subject helps to enhance commitment levels by taking necessary actions and decussions before an employee quits a workplace. As a result of the study, conducted by Ling and Yuen in Malasia among 200 office workers of different age groups, confirms that organizational commitment depends on age and education, as the data was very diverse (Ling, Yuen, 2014). 
According to Ivanova the considered approaches to the classification of types, forms, and also levels of commitment allow revealing the distinctive features of an individual employee or team as a whole. Managers, possessing such knowledge, have the opportunity to make forecasts regarding changes in the loyalty of subordinates, as a result of which they can plan activities aimed at strengthening or increasing it. However, managers must remember: employee behavior can be truly loyal, and can be demonstrative. Therefore, only with in-depth analysis and monitoring of activities and behavior can one reveal the true attitude of the employee to the organization (Ivanova, 2019).

\section{Relationships between career anchors and organizational commitment.}

There were limited number of studies, investigating relationships between Career anchors and organizational commitment. For instance, in research done in 2001 by Hoontan and ChooQuek, a crucial connection between eight career anchors and general satisfaction was identified (Hoontan and ChooQuek, 2001).

According to the research conducted in University of Urmia in Iran, the components of career anchors and organizational commitment are interrelated and have positive impact on each other. Seventy participants were selected among faculty members. The surveyees were given Shein's questionnaire on career anchors and Mayer and Allen's questionnaire on organizational commitment model. Moreover, the author emphasizes the key competences and factors of career anchors that influence organizational commitment. First, technical/functional competence, which means that people try to choose the positions of their interest, rather than managing one. The next competence is general managerial. Those individual who possess this competence are eager to manage and rule others. Third component is called autonomy/ independence, which is natural for employees preferring freedom. The next component having impact on organizational commitment is pure challenge. For those employees it is very important to be responsible for problem solving tasks. Finally, life style plays an important role in individual's motivation to work (Ghalavandi, et al., 2012).
Clinton-Baker in his research paper identifies the connection between organizational commitment, career anchors and staff turnover. Another objective was to find out whether this connection is influenced by different age groups, gender and position. As the main method, the researcher selected the quantitative one. The survey was conducted among 343 retail sector employees, which included management positions and general staff in South Africa. As a result of the survey, career anchors are crucially related to organizational commitment. Moreover, the author discovered that there is strong relationship between organizational commitment and turnover. For instance, participants who are characterized by affective and normative commitment, have lower turnover intention rather than other participants. Finally, the paper reveals the fact, that turnover does not deal with gender, however, it has relationship with age and race. For example, surveyees under 30 , have more desire to leave the organization they work for (Clinton-Baker, 2013).

\section{Conclusion}

Regardless of career orientations, an employee can be both loyal to the organization and disloyal. At the same time, organizational loyalty is associated with a personal index of expectations, reflecting the expectations of the employee regarding the implementation of the motives of professional activity at the time of starting work in the organization. It can be argued that more loyal are employees who, at the time of joining a job, are aimed at the activity itself, at social compensation and / or at self-motivation.

To conclude, relationships between career anchors and organizational commitment are crucial. The studies are conducted in this field in order to help employers and their employees identify optimal working conditions and reduce the staff turnover. Employers have to manage different job aspects, giving some support programs and monitor individuals' emotional state, as motivation is very significant in any workplace. The most important thing is to understand the vision of career path and development.

\section{References}

Allen, N. J., Meyer, J. P., (1990). The measurement antecedents of affective, continuance and normative commitment to the organization. Journal of Occupational Psychology. Retrieved from file://C:/Users/user/Downloads/OrganizationalCommitmentAllen-Meyer1990.pdf

Allen, N. J., Meyer, J. P. (2000). Construct Validation in Organizational Behavior Research: The Case of Organizational Com- 
mitment Norwell, MA: Kluwer Academic Publishers. pp. 285-314.

Ashwin, P. (2006). Changing higher education, First Published, Rout ledge: Taylor Francisco Group.

Aydogmus, C. (2018). Millennials' Career Attitudes: The roles of Career Anchors and Psychological Empowerment. International Journal of Academic Research in Business and Social Sciences, No.8(6), pp. 1-23.

Benson, J., \& Brown, M. (2009). Generational Differences at Work : Do they Matter?

Clinton-Baker, M. (2013). The Relationship Between Career Anchors, Organisational Commitment And Turnover Intention.

Retrieved from http://uir.unisa.ac.za/bitstream/handle/10500/13098/dissertation_clinton-baker_m.pdf?sequence=1\&isAllowed=y

Cohen A. (1993). Organizational Commitment and Turnover: A Met AAnalysis. Academy of managment, pp. 1140-1157

Davis J.B., Pawlowski S., Houston A. (2006). Work commitments of Baby Boomers and Gen-Xers in the IT profession: Generational differences or myth?. Journal of Computer Information Systems, No.46, pp. 43-49.

Galavandi H. (2010). Determination of relationship between quality of work life and career anchors with organizational performance perspective of faculty members in Tabriz, Urmia and Ardabil Universities, Ph.D. Dissertation, university of Isfahen (In Persian).

Ghalavandi H., Arbabisarjou A., Yarmohammadzadeh P., Soltanzadeh V., Iman S., Sokooti N. (2012). Relationship between Career Anchors and Organizational Commitment among Faculty Members. Retrieved from http://dx.doi.org/10.5296/jse.v2i1.1439 Gray J.L., Starke F. A. (1988). Organizational Behavior, Concepts and Applications, p. 6.

Jans N.A. (1989) Organizational commitment, career factors and career/life stage. Journal of Organizational Behavior, No.10, pp. 247-266.

Jaros S. (2007). Meyer and Allen Model of Organizational Commitment: Measurement Issues. The Icfai University Press. Retrieved from file://C:/Users/user/Downloads/Meyer-Allen\%20Org.Commitment\%20Measures\%20-\%20Article.pdf

Ivanova N.E. (2019) Loyalnost personala kak fenomen [Staff loyalty as a phenomenon] Scientific bulletin of the Southern Institute of Management, No. 2, pp. 23-28.

Ling L. X., Yuen J. L., (2014). Organizational Commitment of White Collar Employees in Damansara Heights, Kuala Lumpur, Journal of Social Economics Research, Conscientia Beam, vol. 1(7), pp. 156-168. 259.

O’Malley M. (2000) Creating commitment: How to attract and retain talented employees by building relationships that last, $p$.

Musto J. A. (2003). Organizational Commitment: A Comparison Between Two Generations of Employees in the. Education Masters, p. 134.

O’Reilly C., Chatman J. (1986). Organizational Commitment and Psychological Attachment: The Effectsof Compliance, Identification, and Internalization on Prosocial Behavior. Journal of Applied psychology, 492-499.

Ozhiganova E. M. (2015). Teoriya pokolenii N. Howa and V. Straussa. Vozmozhnosti prakticheskogo primeneniya. Biznesobrazovanie v ekonomike znanii, No.1 (1), pp. 94-97.

Polyanskaya E. N. (2014). Karyernye orientacii sovremennoi rossiyskoi molodeji [Career attitudes of the modern youth] Modern problems of the science and education, No.159.9 (075.32), pp. 123-132.

Rocha F.S., Cardoso L., Todera N. (2008). The importance of organizational commitment to knowledge management. Comportamento Organizational E Gestao, No.14(2), pp. 211-232.

Schein, E. H. (1990). Career Anchors: Discovering Your Real Values. San Diego, CA: Pfeiffer \& Company.

Schein, E.H. (1996). Career anchors revisited: Implications for career development in the 21 st century. The Academy of Management Executive, No.10(4), pp. 80-88.

Shindryaeva I. V. (2015). Professionalnye tsennostnye orientacii molodeji v kontekste pokolencheskoi teorii [Professional value orientations of the youth in the framework of psychological theory] Vestnik PAGS, No.6(51), pp. 144-148.

Silva R. C., Trevisan L. N., Veloso E. F., Dutra J. S. (2016). Career anchors and values from different career management perspectives. Review of Business Management, No 3, pp.65-72.

Tsaritstentsaeva, O. P., (2010). Karyernye orientacii sovremennoi molodeji: teoriya, eksperiment, trening. [Career attitudes of the modern youth: theory, experiment, training] International journa of the applied and fundamental research, No.6, pp. 73-74

Zangaro, G. (2001). Organizational commitment: A concept analysis. Nursing Forum, No.36(2), pp. 14-22.

Zharkikh N. G., Vasina N. V., \& Kostyrya S. S. (2014). Motivatsiya karyernoi orientacii [Career motivation of the attitudes] Uchenye zapiski OGU. Seriya: Gumanitarnye I socialnye nauki, No.4, pp. 343-346.

\section{Литература}

Allen N. J., Meyer J. P. The measurement antecedents of affective, continuance and normative commitment to the organization. Journal of Occupational Psychology. Retrieved from file:///C:/Users/user/Downloads/OrganizationalCommitment-Allen-Meyer1990.pdf. - 1990 .

Allen N. J., Meyer J. P. Construct Validation in Organizational Behavior Research: The Case of Organizational Commitment Norwell, MA: Kluwer Academic Publishers. - 2000. - P. 285-314.

Ashwin, P. Changing higher education, First Published, Rout ledge: Taylor Francisco Group. - 2006, 245 p.

Aydogmus, C. Millennials' Career Attitudes: The roles of Career Anchors and Psychological Empowerment // International Journal of Academic Research in Business and Social Sciences. - 2018. - No.8(6). - P. 1-23.

Benson, J., \& Brown, M. Generational Differences at Work: Do they Matter? - 2009. - 125 p.

Clinton-Baker, M. The Relationship Between Career Anchors, Organisational Commitment And Turnover Intention. Retrieved 
from http://uir.unisa.ac.za/bitstream/handle/10500/13098/dissertation_clinton-baker_m.pdf?sequence=1\&isAllowed=y. -2013 .

Cohen A. Organizational Commitment and Turnover: A Met AAnalysis. // Academy of management. - 1993. - P. 1140-1157

Davis, JB \& Pawlowski, Suzanne \& Houston, A. Work commitments of Baby Boomers and Gen-Xers in the IT profession: Generational differences or myth? // Journal of Computer Information Systems. - 2006. - No.46. - P. 43-49.

Galavandi H. Determination of relationship between quality of work life and career anchors with organizational performance perspective of faculty members in Tabriz, Urmia and Ardabil Universities, Ph.D. Dissertation, university of Isfahen (In Persian). $2010,258 \mathrm{p}$.

Ghalavandi H., Arbabisarjou A., Yarmohammadzadeh, P., Soltanzadeh, V., Iman, S., Sokooti, N. Relationship between Career Anchors and Organizational Commitment among Faculty Members. Retrieved from http://dx.doi.org/10.5296/jse.v2i1.1439. - 2012 Gray J.L., Starke F. A. Organizational Behavior, Concepts and Applications. - 1988. -6 p.

Jans N.A. Organizational commitment, career factors and career/life stage // Journal of Organizational Behavior. - 1989. No.10. - P. 247-266.

Jaros S. Meyer and Allen Model of Organizational Commitment: Measurement Issues. The Icfai University Press. Retrieved from file:///C:/Users/user/Downloads/Meyer-Allen\%20Org.Commitment\%20Measures\%20-\%20Article.pdf. - 2007

Иванова Н.Е. Лояльность персонала как феномен // Научный журнал Института Менеджмента. - 2019. - № 2. - С. 23-28.

Ling L. X., Yuen J. L. Organizational Commitment of White Collar Employees in Damansara Heights, Kuala // Lumpur, Journal of Social Economics Research, Conscientia Beam. - 2014. - No.1(7). - P. 156-168. $259 \mathrm{p}$

O'Malley M. Creating commitment: How to attract and retain talented employees by building relationships that last. - 2000. -

Musto J. A. Organizational Commitment: A Comparison Between Two Generations of Employees in the. Education Masters. 2003. $-134 \mathrm{p}$.

O'Reilly C., \& Chatman J. Organizational Commitment and Psychological Attachment: The Effectsof Compliance, Identification, and Internalization on Prosocial Behavior // Journal of Applied psychology. - 1986. - P. 492-499.

Ожиганова Е.М. Теория поколений Н. Хоува и В. Штрауса. Возможности практического применения // Бизнес-образование в экономике знаний. - 2015. - No.1 (1). - С. 94-97.

Полянская Е.Н. Карьерные ориентации современной российской молодежи // Современные проблемы науки и образования. - 2014. - № 2. - С. 25-32.

Rocha F.S., L. Cardoso and N. Todera. The importance of organizational commitment to knowledge management // Comportamento Organizational E Gestao. - 2008. - No.14(2). - P. 211-232.

Schein E. H. Career Anchors: Discovering Your Real Values. San Diego, CA: Pfeiffer Company. - 1990. - 345 p.

Schein E.H. Career anchors revisited: Implications for career development in the 21st century //The Academy of Management Executive. - 1996. - No.10(4). - P. 80-88.

Шиндряева И. В. Профессиональные ценностные ориентации молодежи в контексте поколенческой теории // Вестник ПАГС. - 2015. - №6 (51). - С. 59-64.

Silva R. C., Trevisan L. N., Veloso E. F., Dutra J. S. Career anchors and values from different career management perspectives // Review of Business Management. - 2016. - No 5. - P. 123-132.

Цариценцева О.П. Карьерные ориентации современной молодежи: теория, эксперимент, тренинг // Международный журнал прикладных и фундаментальных исследований. - 2010. - № 6 - С. 73-74.

Zangaro, G. Organizational commitment: A concept analysis // Nursing Forum. - 2001. - No.36(2). - P. 14-22.

Жарких Н.Г., Васина Н.В., Костыря С.С. Мотивация карьерной ориентации // Ученые записки ОГУ. Серия: Гуманитарные и социальные науки. - 2014. - No.4. - С. 343-346. 